\title{
INTEGRATED PERFORMANCE MEASUREMENT OF LOCAL HOTELS IN THE CONTEXT OF A GLOBAL TOURISM DESTINATION: A CASE STUDY OF SAMUI ISLAND, THAILAND
}

\author{
Somnuk Aujirapongpan* and Kanittha Pattanasing \\ School of Management, Walailak University, \\ 222 Thasala, Nakornsrithammarat 80160, Thailand \\ ${ }^{*}$ Corresponding author: asomnuk@wu.ac.th
}

Published online: 30 June 2020

To cite this article: Aujirapongpan, S., \& Pattanasing, K. (2020). Integrated performance measurement of local hotels in the context of a global tourism destination: A case study of Samui Island, Thailand. Asian Academy of Management Journal, 25(1), 1-23. https://doi. org/10.21315/aamj2020.25.1.1

To link to this article: https://doi.org/10.21315/aamj2020.25.1.1

\begin{abstract}
This is a qualitative study with the objective to search for the patterns and directions in an integrated performance measurement of local hotels through secondary data from existing research collections and primary data from personal in-depth interviews with 12 local hotel administrators in the global tourism destination of Samui Island, Thailand. In this study, we found that the performance measurement of local hotel businesses on Samui Island, Thailand, a global tourism destination, was composed of various components. Each component was integrated; the performance measurements of each component are not undertaken separately. The financial aspect is not the sole focal component; rather, it is connected to other aspects, i.e., the operation and stakeholder relationship. The financial aspect of the local hotels, on the other hand, includes measurements of income and return on investment. In addition, the operation of the businesses emphasises the satisfaction with the customer service, while the stakeholder relationship stresses customer loyalty. Importantly, a sense of ownership on the part of the personnel, trust in their colleagues, and a sense of being a part of the community in which the businesses operate are all taken into consideration.
\end{abstract}

Keywords: integrated performance measurement, local hotel, family business, tourism, Samui Island

(C) Asian Academy of Management and Penerbit Universiti Sains Malaysia, 2020. This work is licensed under the terms of the Creative Commons Attribution (CC BY) (http://creativecommons. org/licenses/by/4.0/). 


\section{INTRODUCTION}

According to the United Nations World Tourism Organization (UNWTO)'s 2017 report, which ranks the popular global tourism destinations based on two important indicators, i.e., the number of foreign visitors and the revenue earned from foreign visitors, in 2016, Thailand received 32.6 million from the total 1,235 million global tourists, meaning that Thailand ranks ninth in the world in terms of the greatest number of foreign tourists. Furthermore, Thailand received USD49.9 billion in revenue, ranking third in the world. The UNWTO forecasted that by 2030, the revenue from global tourism would increase by USD1.8 billion dollars (UNWTO, 2017). The enormous expansion of tourism has accordingly affected the expansion of the main business in the tourism industry, i.e., hotel businesses in Thailand. More than $50 \%$ of the tourists to Thailand have seaside sightseeing as their main objective. The most popular seaside provinces are Phuket, Chonburi (Pattaya) and Surathani (Samui) (Ministry of Tourism and Sport, 2015).

The expansion of tourism and the rise of Thailand to a world-class tourism destination has resulted in the growth of investment in hotel businesses and increasingly strong competition, especially among local hotels, which have faced formidable challenges from the investment and expansion of large foreign chain hotels that have world-class standards of service, including Marriott, Minor Hospitality, Hilton Worldwide, and Accor Hotels. Amid increasingly stringent competition, local hotel businesses need to accommodate and initiate various strategies to develop their services and increase their potential to operate more efficiently. However, to determine whether a business has accomplished its goal or successfully implemented its strategy, it is important to know how performance is measured in that business, i.e., what criteria are used. In the past, measurements primarily assessed the financial operation, i.e., profit, return on investment (ROI), and the growth of productivity (Rajnoha et al., 2016; Ferreras \& CrumptonYong, 2018). Essentially, such measurement of financial performance is meant to consider solely the result of the operation from the accounting data. Additionally, it is a measurement of the past that is unable to provide information on future beneficial scenarios, i.e., customer demands, competitors' operations, and the on-going development of their own businesses. In addition, it lacks relevancy to the businesses' strategies (Laitinen, 2002). Hence, in the age of the information and communication revolution in which the internal and external business environments are undergoing drastic changes, a purely financial measurement of an organisation's operational success may not be sufficient.

Consequently, in the past decade, academia and practitioners have presented and discussed various conceptual frameworks and procedures that will help in the 
development of an integrated performance measurement (IPM) system (Kaplan \& Norton, 2004; Chenhall \& Langfield-Smith, 2007), using the most appropriate approaches and criteria that comprehensively cover all the various aspects of the operation of the organisations while remaining consistent with the organisation's strategy (Giovannoni \& Maraghini, 2013). Nevertheless, whether an organisation will be successful does not depend merely on these measurement criteria. The payment system is another important factor, as it needs to be a motivating factor leading the employees to work towards meeting the measurement criteria. Hayes and Schaefer (1998) state that the future prospect of an operation depends on whether the present payment can stimulate the employees to work to their maximum capability. Brata and Juliana (2014) proposed that with regard to the installation of performance measurement systems and reward systems in an organisation, control system designers should be aware of and consider the dimensions of employee perceptions of justice.

The above discussion therefore indicates that for an organisation to achieve its goals, there must be an IPM in which the various criteria, both financial and nonfinancial, are integrated. These criteria must also be related to the organisation's strategy and connected to its payment system. Therefore, the authors pose two research questions:

$\mathrm{RQ}_{1}$ : How can local hotels in a global tourism destination, which in this case study is Samui Island, utilise IPM?

$\mathrm{RQ}_{2}$ : In which direction should the local hotels on Samui Island develop IPM to make their operations more efficient?

The paper poses two research objectives: (1) to study the patterns in and future direction of the IPM of local hotels in a global tourism destination via the case study of Samui Island in Thailand; and (2) to present a model of IPM for local hotels in a global tourism destination. This research was performed to investigate local hotel businesses, most of which are family-owned businesses with unique administrative characteristics that are different from those of general organisations managed by professional administrators and a focus on profit-making as well as sustainability. Huerta et al. (2017) stated that any size family business involves people linked by familial ties in different aspects of the business, i.e., employees, shareholders, or advisors. Most of the research on family businesses focuses on studying the internal relationships among the businesses' family members, problems regarding the inheritance of the businesses and the earnings of the businesses. There have been few studies, globally as well as in Thailand, that study strategic management systems or the introduction of the concept of a strategic 
controlling system to build competitive advantage (Salvato \& Moores, 2010). This study presents the utilisation of IPM system, which is a strategic controlling system, in the administration of a family business, namely a local hotel in a tourist destination. The study will provide a deeper understanding of that system so that it can be applied to the development of IPM system to increase the potential of family businesses, especially hotels, in the future.

\section{LITERATURE REVIEW}

\section{Performance Measurement System}

Performance measurement is a quantitative measurement process used in assessing the efficiency and effectiveness of an operation in the past (Neely et al., 1995; 2005) through the appropriate acquisition, collation, sorting, analysis, and interpretation of the data. If there is no processing of any data, a measurement process will not be complete, and decisions and changes will not be able to be made later. Neely et al. (2002) explained the characteristics of a good performance measurement system as follows: (1) must present business balance; (2) must reflect the results of the organisation's operation; (3) should be composed of multiple dimensions; (4) must reflect a complete picture of the business; (5) should connect to every duty and every rank in the organisation; and (6) must be able to provide information for the examination of the results of the performance in the past, and must be able to provide guidance for the operation in the future.

A performance measurement system is essential for the successful administration of an organisation because it plays a vital role in the implementation of the business strategy, helping guide the organisation's strategy to develop desirable behaviours and effects. Having a good competitive strategy in itself cannot lead to a successful organisation if the implementation is not efficiently actualised (Roshan \& Jenson, 2014). Performance measurement can produce many benefits if implemented, i.e., determining whether the results of the operation of the organisation have improved or deteriorated and how, acting as a warning signal so that an organisation can adapt a strategy to face the dangers to its success in a timely fashion; enabling prioritisation of the organisation's projects through the identification of the strong and weak points, with resources being allocated to the latter for resolution. In addition, performance measurement is also utilised as a marketing instrument signalling to the customers information about the organisation's excellence and comparisons with the organisation's strongest competitors so that it can develop and improve its performance (Abu-Suleiman et al., 2004). Performance measurement is also used to change employees' behaviour by building motivation and offering 
rewards (Roshan \& Jenson, 2014; Meyer, 2002), which will reduce biases in the measurement of employee performance. Therefore, the performance measurement system plays an important role in helping executives focus on achieving objectives and using them as important agents for change. This improves the performance of both individuals and organisations (Rasid et al., 2017).

Knowledge of performance measurements is not specific to any discipline. We therefore see research on performance measurement in a variety of different disciplines, i.e., accounting, management, human resource administration, operation management, marketing, strategic management, and organisation behaviour (Marr \& Schiuma, 2003; Srimai et al., 2011). In the last 30 years, there have been several important performance measurement concepts proposed, while many changes have occurred as well. The conventional concepts from the $1880 \mathrm{~s}$ to the 1980s emphasised the importance of cost and the accounting system and focused primarily on financial measurements, i.e., profit, productivity, and ROI (Ferreras \& Crumpton-Yong, 2018).

Between the 1980s and 1990s, there were many studies on performance measurement resulting in a multi-dimensional perspective rather than focusing simply on the financial aspect (Bourne et al., 2000; Nudurupati et al., 2011; Bititci et al., 2012). In the last several years, there have been a large number of academics and practitioners who have presented and discussed the conceptual framework of and process of developing an IPM system (Kaplan \& Norton, 2004; Chenhall \& Langfield-Smith, 2007) in an attempt to guide the future direction of such systems and determine the criteria to use when choosing the most appropriate measurement that covers various aspects of the results of the operation of the organisation. At the same time, it must be ensured that all elements are in line with the strategy of the organisation (Giovannoni \& Maraghini, 2013). Hence, many academics in various disciplines tried to have attempted to find better methods of connecting the performance measurement to the organisation's strategy (Langfield-Smith, 1997; Neely, 2005). Increasing amounts of research indicate that the use of a strategic performance measurement system is more beneficial than the usage of an accounting measurement system (Ittner et al., 2003).

Based on the preceding discussion, it is clear that at present, various organisations have paid a great deal of attention to performance measurement systems because they constitute an efficient instrument that can be used to monitor and strategically control the operation of the organisation (Kaplan \& Norton, 1996; Bourne et al., 2000; Simons, 2000; Schneier, 1991). The performance measurement of an organisation will stress the importance of not only the financial aspect but also the other business aspects, i.e., the customers and methods of remaining relevant 
and balanced. Giovannoni and Maraghini (2013) explained that the patterns in performance measurement must involve the integration of various measurements that are not only related to the value creation process and function of the organisation but that are also all different, i.e., the operation, finances, marketing, research and development, or are related to the perspectives of the stakeholders, i.e., customers, shareholders, and employees. In addition, Chenhall and Langfield-Smith (2007) suggested that an IPM system must connect with various measurements that reflect the organisation's strategy. Additionally, there must be a relationship between the strategic objectives and the operation throughout the value chain.

\section{Integrated Performance Measurement}

\section{Balance Scorecard}

The model of IPM that is popular and widely applied among businesses is the Balanced Scorecard (BSC). It is a multi-dimensional tool that is connected specifically with the organisation's strategy. It was developed at the Harvard Business School by Kaplan and Norton and has been widely used by production and service organisations, non-profit organisations, and state organisations all over the world since the concept was publicised in 1992. The BSC concept begins with the assumption that relying solely on financial performance measurement is not enough, as financial measurement is a late indicator that reports the status of the operation in the past. Porter (1992) explains that relying only on financial performance measurement is not sufficient because it sacrifices long-term value creation for short-term operation results. The BSC methodology still uses financial performance measurement but it is supplemented by driving indicators that lead to future financial results (Kaplan \& Norton, 1996; 2001). In that light, the BSC comprises four perspectives as follows:

1. Financial perspective. The general target of the profit-making organisation is to increase the value of the business for the shareholders. There are two common methods a business uses to increase the value of its assets - increasing revenue and empowering its productivity potential. The revenue growth strategy in general comprises two components: building income earnings from new marketing, new products, and new clients; and increasing sales to returning clients through intimate relationships, including the cross-sale of various products and services, and providing comprehensive problem solving. In general, the strategy for increasing productivity is composed of two components: the improvement of the cost structure, which directly and indirectly reduces expenditures; and more efficient use of assets. 
2. Customer perspective. The essence of the business strategy is the customer value proposition, which refers to the identity of the product, price, service, relationship, and image that the company presents to its customers.

3. Internal process perspective. The administrator must define the important internal processes in which the organisation must excel. These processes must enable the economic units to deliver the values presented to the customers, impressing and retaining the customers, and must be able to satisfy the shareholders with an excellent financial return. The internal measurement of the business therefore emphasises the internal processes that strongly affect the satisfaction of the customers to achieve the financial objective of the organisation.

4. Learning and growth perspective. Learning and growth is an infrastructure that an organisation must develop to support the growth and development of its organisation in the long run. There are three sources of learning and growth: humans, the system, and the working process of the organisation. The objectives pertaining to finances, customers, and the internal process of a BSC in general involve identifying gaps between the expected results and the capability of the personnel, systems, and the work processes that formerly existed. An outstanding performance that can close these gaps requires investment in the development of the skills of the personnel, the development of information and systems, and the adjustment of the routine work and work processes of the organisation.

\section{The Performance Prism}

The four perspectives of performance measurement along with the concept of the BSC may not be enough to build sustainability. Neely et al. (2001) have suggested that in performance measurement, the organisation should place emphasis on all groups of stakeholders. BSC performance measurement stresses the importance of shareholders and customers, with no mention of employees, suppliers, alliance partners, or intermediaries. Nor does the BSC mention the regulators, local community, or other agencies. All these agencies, however, may affect the efficiency and success of the organisation (Neely et al., 2001; Neely et al., 2002). Therefore, in 2001, Andy Neely and his colleagues presented a new concept in performance measurement called the Performance Prism (PP), which is composed of the following five perspectives:

1. Stakeholder satisfaction. This perspective focuses on the answer to the question: Who are the stakeholders of the organisation? What do they want? 
2. Strategies. It is important to answer the question regarding which strategies an organisation uses to respond to the demands of the stakeholders. Previously, it was controversial whether the measurement should come from the strategies, while actually the purpose of strategies in an organisation is only to deliver value to some of the shareholders. Therefore, first the stakeholders and their desires should be identified. It is possible that by doing so, it will become clear which strategies will ensure that the needs of the stakeholders are satisfactorily addressed.

3. Processes. It is vital to determine which processes are important for the implementation of the strategies. Processes mean general procedures in doing business, i.e., the development of new products and services, the creation of and responses to demands, planning, and organisational administration.

4. Capabilities. It is necessary to determine which capabilities an organisation must possess to achieve organisational excellence. Capabilities include personnel, work practices, technology, and infrastructure that enable the economic process (both in the past and in the future), forming an important base for the building of competitive capability.

5. Stakeholder contribution. It is necessary to determine what type of benefits an organisation wants from stakeholders so that it can maintain and develop its capabilities.

The performance prism is a performance measurement concept founded on the awareness that an organisation not only delivers value to the stakeholders but also needs the stakeholders to participate in the organisation, i.e., the personnel need a safe work place, good salary, acceptance, and opportunities to grow in the organisation's career path. On the other hand, the organisation needs its personnel to participate in the business, offering suggestions and recommendations, developing expertise, and professing business loyalty. Such a relationship includes all groups of stakeholders, i.e., distributors, customers, office personnel, alliance partners, investors, and the local community.

\section{METHODOLOGY}

This study was an area-based study. Samui Island was the location chosen by the researchers because it is one of the most important tourism destinations in the world and is a province in the southern region, making it convenient for data collection. The data were collected from local hotels, most of which are family businesses, with unique administrative characteristics that are different from those of the chain 
hotels operated by professional administrators. Therefore, they also have different measurement and management control systems. The objective of this research was to study some specific phenomena from many points of view to identify the patterns in and future directions of IPM in local hotels. By obtaining information from both in-depth interviews and secondary sources in a case study on Samui Island, the goal was to develop models of IPM for local hotels located in a world tourism destination. The results will be useful for future research on enhancing the service standards for local hotels in this area through strategic control systems such as IPM systems.

The scope of the study was local hotels with local Thai owners and administrators. These local hotels were developed and are managed by these Thai owners and administrators located on Samui Island, Suratthani Province, which is an important world tourism destination in Thailand. The data were collected from March 2018 to December 2018. The process of the study was as follows:

1. The researchers collected the secondary data from existing materials, i.e., books, articles, academic documents, and related research papers to study IPM; this information was presented in the literature review. Then, the researchers consulted two academics who are experts in performance measurement and management to draft the interview protocol and to validate its content, which was based on the theoretical literature review. After that, the structured open-ended questions about IPM were finalised and used to collect the primary data through interviews with the sample of local hotel administrators.

2. The researchers collected primary data from 12 local hotels that were classified into three categories. The first category was 5 -star rated standard hotels, the second category was 4-star rated standard hotels, and the third category was 3-star rated standard hotels. In each category, 4 hotels were identified that were willing to participate. In-depth interviews were conducted with 12 administrators of the selected local hotels on Samui Island to study the systems and IPM process, including the important components and indicators selected by the hotels and their implementation. A content analysis was conducted to analyse the interview data.

3. The researchers analysed the interview data using the content analysis technique by interpreting and coding the data obtained from the interview recordings. The results from the interviews were coded and classified into four main areas (i.e., the components, processes, indicators, and implementation of IPM). Relevant data were classified into those categories and further interpreted to be formed into sets of knowledge constituting answers to the research questions and research objectives. The details of these results are presented in the next discussion. 


\section{RESULTS}

Interviews with the administrators of local hotel businesses in Samui Island show that there are important issues in the IPM system used by the businesses that can be applied for the development of IPM system of the local hotel businesses to increase their competition capabilities with the international chain hotel businesses, as explained in the following discussion.

\section{IPM Components}

Interviews with the administrators of the local hotels showed that the administrators stressed the importance of various components of performance measurement. In addition, there was an integration of each component, i.e., the performance measurement was not undertaken in a fragmented fashion and neither was the financial aspect the sole focal component; rather, it was connected with other components, i.e., operation and stakeholder relationships. Financially, the administrators saw profits as the prime target in the business operation, as the local hotel entrepreneurs were investors themselves. The reason to see profits as the prime target, as explained by one local hotel administrator was that, "Some of the investment was borrowed. It was therefore necessary to examine the profits of the business operation so that the loan or the interest from the loan could be repaid." In addition, the administrators gave special importance to work efficiency and efficacy in the operation.

From the interviews, it is evident that the administrators had special regard for efficiency and the various benefits of resource utilisation. For example, eight local hotel administrators shared that "we focused on building personnel who have multiple skills and are capable of working in many sections." One local hotel administrator said that "we controlled costs in various dimensions of the operation, i.e., the choice of using water-saving devices, energy-saving light bulbs, one keycard for one room to avoid leaving the key-card in the box when the guests are out of the room, and using air conditioner censors to enable the air conditioner to start working after the door is tightly closed."

On the other hand, the administrators perceived that for a business to survive long-term competition with the chain hotels, apart from the operation cost and profits that need constant monitoring, customer satisfaction was a crucial concern. One local hotel administrator said, "Naturally, local hotels are at a disadvantage, having fewer facilities compared to chain hotels. The former, however, have the advantage in terms of location, as most of their land is hereditary. The advantage in 
location and the emphasis given to service quality are the strengths of local hotels that attract customers."

The administrators often urged their personnel to hold service quality as their prime duty by connecting it to the return, both in money and non-monetary terms, on services that increase customer satisfaction. For example, all local hotel administrators shared that "we act out of appreciation and reward the personnel who receive customer compliments."

The interviews revealed that local hotel administrators also stressed the importance of community relationships, conceiving of the community as relatives who help each other, participating in community activities, and respecting the community's views and acceptance of the hotels. One local hotel administrator said that "we recruited hotel personnel from acquaintances in the community. The administration and supervision of the local hotels are thus are in line with family relationships and are more flexible than those of the standardised chain hotels in general."

\section{IPM Processes}

The interviews show that, with regard to participation in the setting of the measurement indicators, the administrators who were the business owners were the ones who chose the measurement indicators. Five local hotel administrators shared that "although hotel personnel were allowed to participate in the brainstorming session, in the end, the administrators would be the ones who made the decisions."

The administrators examined past performance and considered the present business environment context as the basis on which the business targets and measurement indicators were determined. The administrators were the ones who relayed the targets and indicators to the organisations' members and monitored the results of the measurement moving forward. Generally, the process was relayed and followed in each meeting agenda. In the case that the administrators found that an indicator was not consistent with the objectives or the existing environment had changed, the administrators would change the set indicators. The hotel personnel cordially accepted changes in the aforementioned indicators and cooperated in working towards the targets set by the administrators, perhaps because the personnel had confidence and faith in the administrators, who often were the owners of the businesses. The researcher deduced the patterns and processes involved in the setting of hotel business indicators, as shown in Table 1. 
Table 1

IPM processes of local hotels

Details
$\begin{aligned} & \text { Present assessment: Assessing the hotel capability in the past and } \\ & \text { the present, including the environment in terms of the competition, } \\ & \text { policies, society, economy, and technology to determine the issues } \\ & \text { that need improvement and/or the target expectations. } \\ & \text { Indicators setting: Setting of indicators to use as criteria in examining } \\ & \text { the desired objectives of the hotels. } \\ & \text { Implementing: Disseminating the indicators to the responsible } \\ & \text { sections of the hotel to collect data according to the set criteria. } \\ & \text { Monitoring: Reporting of the results regarding the indicators in } \\ & \text { a specified time sequence, comparing the actual results with the } \\ & \text { expected ones, and finding directions for improvement to achieve the } \\ & \text { expected targets. } \\ & \text { Revision: Examining the indicators to ensure they are consistent with } \\ & \text { the objectives and the changing environment, to prevent assessing } \\ & \text { issues that are unimportant for the hotels. }\end{aligned}$

Therefore, it can be concluded that in the process of setting performance measurement indicators, the business administrators or owners are the ones who determine the targets and objectives and disseminate them to the responsible personnel along hierarchical lines. The relevant staff or section heads can propose their viewpoints regarding the setting of indicators and targets. However, the administrators or owners decide which indicators and targets are chosen. Additionally, the administrators try to push their personnel at all levels to take part in the mobilisation of the operation towards the selected indicators and results. There is close follow-up in joint meetings with section heads to assess and find ways to improve if the actual results of the measurement deviate from the expected results.

\section{Components and IPM Indicators}

After the interviews with the local hotel administrators on the usage of components and performance measurement indicators, the researcher sorted the data into more focused issues and grouped the data with the same meaning and similar stories. The data were divided along the main components of performance measurement indicators into three sub-components, i.e., the financial aspect, the operation aspect, and the stakeholder relationship aspect. The details are in Table 2. 
Table 2

IPM components and indicators used by local hotels

\begin{tabular}{|c|c|c|}
\hline $\begin{array}{l}\text { Main } \\
\text { components }\end{array}$ & Minor components & Indicators \\
\hline \multirow[t]{3}{*}{$\begin{array}{l}\text { Financial } \\
\text { aspect }\end{array}$} & Income and return & $\begin{array}{l}\text { Difference between actual sales and forecasts } \\
\text { Net profit } \\
\text { Net profit ratio } \\
\text { Sales growth rate }\end{array}$ \\
\hline & $\begin{array}{l}\text { Efficiency in resource } \\
\text { utilisation }\end{array}$ & $\begin{array}{l}\text { Cost change rate } \\
\text { Difference in actual cost and budget } \\
\text { Occupancy rate }\end{array}$ \\
\hline & & Cost per occupancy rate \\
\hline \multirow[t]{3}{*}{ Operation aspect } & Service quality & $\begin{array}{l}\text { Service period } \\
\text { Period needed to resolve customer problems } \\
\text { Number of customer compliments on manners, } \\
\text { friendliness and service } \\
\text { Number of reports of fraud }\end{array}$ \\
\hline & Facilities and availability & $\begin{array}{l}\text { Level of customer satisfaction with cleanliness } \\
\text { Level of customer satisfaction with facilities } \\
\text { Time needed for room maintenance }\end{array}$ \\
\hline & $\begin{array}{l}\text { Knowledge and } \\
\text { capability }\end{array}$ & $\begin{array}{l}\text { Hours of training } \\
\text { Number of prizes and rewards from various } \\
\text { organisations } \\
\text { Rating of personnel's competency }\end{array}$ \\
\hline \multirow[t]{4}{*}{$\begin{array}{l}\text { Stakeholders } \\
\text { relationship } \\
\text { aspect }\end{array}$} & $\begin{array}{l}\text { Sense of ownership of } \\
\text { the personnel }\end{array}$ & $\begin{array}{l}\text { Level of work satisfaction and happiness of the } \\
\text { personnel } \\
\text { Turnover rate } \\
\text { Number of absences, leave days, and days late to } \\
\text { work } \\
\text { Number of hours participating in activities } \\
\text { Number of programmes enhancing hotel interests }\end{array}$ \\
\hline & Customer loyalty & $\begin{array}{l}\text { Level of customer satisfaction } \\
\text { Number of customer complaints and suggestions } \\
\text { Rate of returning customers, classified by ethnic } \\
\text { group } \\
\text { Rate of referrals, classified by ethnic groups } \\
\text { Rate of new customers, classified by ethnic group }\end{array}$ \\
\hline & $\begin{array}{l}\text { Business partners/ } \\
\text { alliance's trust }\end{array}$ & $\begin{array}{l}\text { Rate of timely repayment } \\
\text { Rate of non-performing loans }\end{array}$ \\
\hline & $\begin{array}{l}\text { A sense of being a part of } \\
\text { the community }\end{array}$ & $\begin{array}{l}\text { Number of social and community activities } \\
\text { participated in each year } \\
\text { Number of blood donations each year } \\
\text { Number of social projects each year } \\
\text { Amount of social donations each year }\end{array}$ \\
\hline
\end{tabular}




\section{Implementation of Performance Measurement Results}

The interviews showed that the administrators had implemented performance measurement results in various ways:

1. In improving service processes, especially improving service processes derived from the customer satisfaction rate. The administrators were frequently energetic and stressed the importance of instantly improving services that were perceived as unsatisfactory by the customers.

2. In awarding prizes and special payments to the personnel, i.e., bonus payments, salary increases, or position promotions.

3. In setting new targets based on past performance results that the administrators used when reviewing the indicators and resetting new targets. The resetting of new targets is often consistent with the past performance.

4. In comparing the hotels with their competitors, especially between families. Most of the administrators are the hotel owners, and they are also local people, with their origins in the community. Being the focus of community interest and obtaining community acceptance signify fame and social celebrity for the administrators' families.

All these factors are the driving forces for the administrators to consider the results of the performance measurement when seeking to improve every aspect of the operation.

\section{DISCUSSION}

The study shows that current IPM strategies in local hotels involve performance measurement that is integrated in terms of the financial and non-financial aspects. Financial measurement is common for economic organisations that aim to make profits. However, financial measurement is the indicator merely of the result, whereas the measurement of the causes is often non-financial in nature but is more beneficial in terms of indicating which improvements are needed outside of the financial sector.

To set appropriate indictors, consideration must be given to whether they are consistent with the targets of the organisation. Thus, before setting an indicator, an administrator must have a clear understanding of the strategy and objectives of the 
organisation; without this clear understanding, it is challenging to set appropriate indicators, as different targets need different performance measurements. Tapera (2014) stated that business organisations need to appreciate the importance of crafting and effectively executing strategies to create a sustainable competitive advantage in a highly competitive environment. Thompson et al. (2016) explained that a company with a good strategy and good implementation tends to be more effective than its competitors in the market. On the other hand, a company with an unclear direction, an incomplete strategy or the inability to use its strategy appropriately, may result in financial disaster, long-term risk, and the lack of sufficient management. From the aforementioned statements, it should be clear that setting the strategies and objectives of an organisation is vital to the success or failure of the organisation. An administrator who lacks a clear vision of what his organisation wants in the future can be compared to taking a long walk with no aim and no map. The organisation has no definite direction. The operation has a high probability of going astray.

To be able to clearly indicate what an organisation wants or what its targets are, there must be an analysis of what the stakeholders want and how to respond to their needs. The organisation that is successful in competition is the one that can attract the interest of the various stakeholders. Therefore, the analysis of the needs of the stakeholders is imperative and crucial to the success of the organisation (Neely et al., 2001; Neely et al., 2002). In the local hotels, with administrators and owners who are generally local people and residents of the area, the importance of the stakeholders, especially the social communities surrounding them, is often stressed. On the other hand, the businesses owners want to be accepted and supported by the society because this will enable their businesses to run smoothly. Social acceptance leads to fame and improvement in their families' status. Therefore, administrators or businesses owners always engage in community development to make the community a better place to live. These local administrators realise that their social activism will be reflected in positive perceptions of their businesses, which would bring good returns in the future. As Green et al. (2008) stated, the social responsibility of an organisation is an alternative method of building competitive advantage and is a means of ensuring the long-term success of an organisation (Jones et al., 2006; Porter \& Kramer, 2006). Ahmadian and Khosrowpour (2017) stated that the advantages of corporate social responsibility are innovation, brand differentiation, and increased value of the company.

Stakeholders, alliance groups, and business partners are important to an organisation because they deliver necessary resources. Various collaborations are involved in doing business. De Waal et al. (2015) stated that a good-quality alliance affects the capability of the organisation. The research by Purnomo et al. (2018) 
showed that business partnerships significantly influence business performance. The partnerships with suppliers and customers have the greatest effect on the improvement of business performance. Therefore, hotel business administrators must understand that to be successful in doing business, good partners and good alliances need to cooperate with and trust each other. Hence, business honesty and transparent return payments are important as they are essential for maintaining good relationships in the long term.

In addition, there are stakeholders who are customers and personnel. The customer group is a primary stakeholder group that brings revenue to the business. The administrators have to analyse customers' needs and build customer satisfaction by responding to their needs. In a hotel, to make the customers willing to pay, the hotel must deliver services at the level of quality expected by the customers. Pazir and Amin (2015), and Mohsin and Lockyer (2010) stated that given the present fierce competition, the survival of a hotel depends on services that result in customer satisfaction, and service quality helps increase customer satisfaction and loyalty, increase market share, increase the ROI to investors, reduce the risk from price competition, and help create competitiveness (Lu et al., 2015; Knutson, 1988; Haksever et al., 2000; Wuest, 2001).

Good quality service comes from the dedication of the personnel to their work. To make the personnel feel the sense of ownership of the business and motivation to work, the administrators need to take care of their living conditions. The local hotels have been under strong competition pressure, and they are at a disadvantage in terms of the operation revenues, welfare, and return given to the personnel. Many personnel have resigned to work at the chain hotels. The local hotel administrators, therefore, generally care for their personnel like relatives, offering help as members of the family, using a more flexible management code, and paying attention to a fair financial return, i.e., salary and welfare at the same levels as those provided by the chain hotels; attention is also paid to non-monetary returns, i.e., providing security, compliments, and respect. Hayes and Schaefer (1998) stated that measuring whether in the future an organisation will improve and by how much depends on the present payment of personnel, and consequently, whether it can motivate the personnel to be attentive and to work at their full capacity. Plessis et al. (2016) stated that the main factor that leads to a high level of job satisfaction and motivation is the salary.

The family-oriented administrations are caring, flexible, and informal; this results in a more natural work environment that is unrestricted by the standardised orders/ conventions of the chain hotels. This creates an identity for the local hotels that impresses the customers, making them feeling friendly towards the hotel personnel. 
Not surprisingly, a considerable number of customers return to the same local hotel where they stayed previously. As Andersen (2012) stated, in the modern world where changes occur so quickly, for survival, many organisations have tried to build their own unique identities that are different from those of the others, engendering a positive feeling among the personnel.

\section{CONCLUSION}

The study of patterns and direction of IPM in local hotels in a global tourism destination, namely, Samui Island, Thailand, in the context of strong competition, with ethnic differences among the tourists, reveals that at present, these local hotels have ascribed importance IPM that incorporates multi-dimensional indicators and components. The components of performance measurement and the indicators determined by the organisations are consistent with the strategy and targets of the organisations, which want to respond to the needs of all stakeholders, as they, especially the community, ultimately affect the success of the organisation. In addition, it was observed that the businesses must regularly revise their IPM system to make it compatible with the internal and external contexts that keep changing all the time - the tourism season, tourists' ethnicities, and the competition strategies of foreign hotels. From this study, the researcher has identified the models of IPM of local hotels in a global tourism destination, using the data from a case study of Samui Island, as shown in Figure 1.

The findings of this study can be employed to improve local hotel management. First, local hotels must recognise the importance of creating a performance measurement system that integrates all stake-holder requirements; this system should be in line with the strategic objectives of the hotel to enhance service quality and further lead to better service standards that are comparable to those of the chain hotels. Second, local hotels should continuously participate in and maintain relationships with the local communities, as this is a unique characteristic of local hotels and leads to a strong community that will attract tourism to the area. 


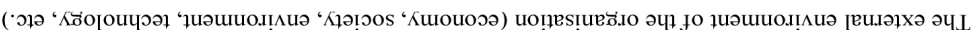

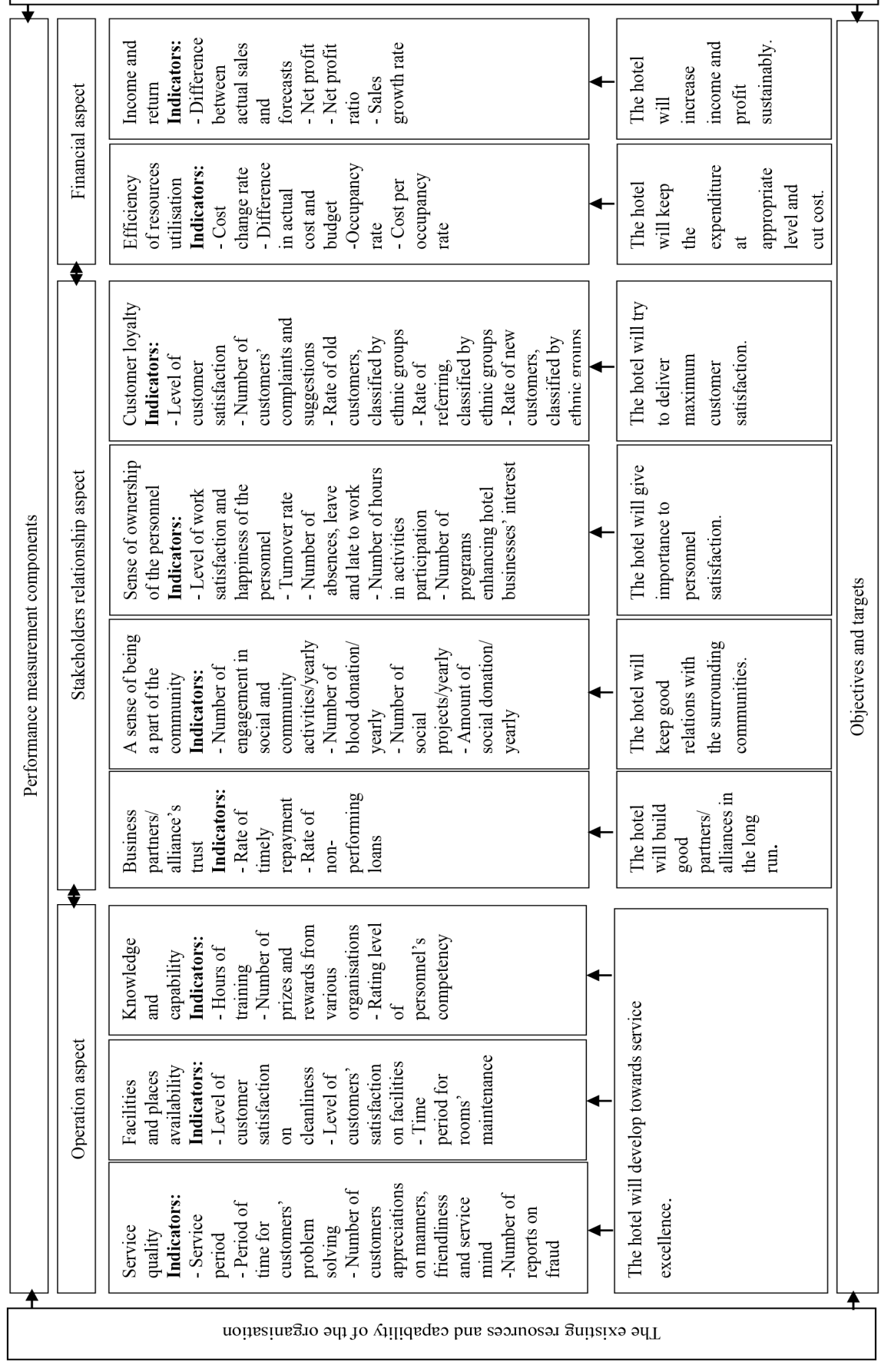

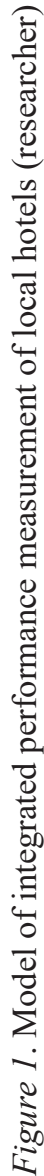




\section{LIMITATIONS OF THE STUDY AND FUTURE RESEARCH}

This study focused on only local hotels with Thai owners in the global tourism destination, Samui Island, Thailand. In order to apply the findings of this study elsewhere, it should first be determined whether the business contexts of Samui Island and the other location are similar. Samui Island is small, but it is a worldfamous tourism destination. Therefore, hotel competition in Samui Island is strong and closely affects the survival and economic growth of local hotels. Samui Island nonetheless still retains the local characteristic of closeness among the community, whereas in large cities, the community relationship aspect is not strong. The application of the findings therefore must take into account two aspects: the close relationship of people in the community, and the position of most of the business owners as members of the community.

In future studies, other stakeholders (e.g., customers and personnel) should be included because they play a major role in performance measurement and management system setting. In addition, there should be comparative studies of local hotels in other global tourism destinations to observe the differences in the usage and direction of IPM, which is crucial for strengthening competitive competency. Furthermore, variables should be developed for use in a quantitative study to gather empirical data that could be analysed to determine patterns appropriate for local hotels in general. The ultimate benefit would be the increasingly wide application of the research findings.

\section{ACKNOWLEDGEMENTS}

This research was partially supported by the new strategic research (P2P) project, Walailak University, Thailand (grant no. CGS-P2P-2562-054).

\section{REFERENCES}

Abu-Suleiman, A., Boardman, B., \& Priest, J.W. (2004). A framework for an integrated Supply Chain Performance Management System [paper presentation]. IEE Annual Conference and Exhibition 2004, University of Texas, Arlington.

Ahmadian, A., \& Khosrowpour, S. (2017). Corporate social responsibility: Past, present, and success strategy for the future. Journal of Service Science, 10(1), 1-12. https://doi.org/10.19030/jss.v10i1.10063 
Andersen, M.A. (2012). A multidimensional model for analyzing employee identification with corporate values: A qualitative reception analysis approach. Qualitative Research in Organizations and Management: An International Journal, 7(2), 209-230. https://doi.org/10.1108/17465641211253101

Bititci, U., Garengo, P., Dörfler, V., \& Nudurupati, S. (2012). Performance measurement: Challenges for tomorrow. International Journal of Management Reviews, 14(3), 305-327. https://doi.org/10.1111/j.1468-2370.2011.00318.x

Bourne, M., Mills, J., Wilcox, M., Neely, A., \& Platts, K. (2000). Designing, implementing and updating performance measurement systems. International Journal of Operations \& Production Management, 20(7), 754-771. https://doi. org/10.1108/01443570010330739

Brata, H., \& Juliana, L. (2014). Performance-based reward systems and perceived justice: A case of motorbike dealer in Pontianak. International Journal of Business and Society, 15(2), 195-214.

Chenhall, R.H., \& Langfield-Smith, K. (2007). Multiple perspectives of performance measures. European Management Journal, 25(4), 266-282. https://doi. org/10.1016/j.emj.2007.06.001

De Waal, A., Goedegebuure, R., \& Hinfelaar, E. (2015). Developing a scale for measuring high performance partnerships. Journal of Strategy and Management, 8(1), 87108. https://doi.org/10.1108/jsma-07-2014-0065

Ferreras, A.M., \& Crumpton-Yong, L.L. (2018). Company success in manufacturing organizations: A holistic systems approach. CRC Press. https://doi. org/10.1201/9781315118314

Giovannoni, E., \& Maraghini, M.P. (2013). The challenges of integrated performance measurement systems: Integrating mechanisms for integrated measures. Accounting, Auditing and Accountability Journal, 26(6), 978-1008. https://doi. org/10.1108/aaaj-04-2013-1312

Green, S.D., Harty, C., Elmualim, A.A., Larsen, G.D., \& Kao, C.C. (2008). On the discourse of construction competitiveness. Building Research and Information, 36(5), 426-435. https://doi.org/10.1080/09613210802076666

Haksever, C., Render, B., Russell, R.S., \& Murdick, R.G. (2000). Service management and operations (2nd ed.). Prentice Hall.

Hayes, R.M., \& Schaefer, S. (1998). The effect of bonus schemes on accounting decisions. Journal of Accounting and Economics, 7, 85-107.

Huerta, E., Petrides, Y., \& O’Shaughnessy, D. (2017). Introduction of accounting practices in small family businesses. Qualitative Research in Accounting \& Management, 14(2), 111-136. https://doi.org/10.1108/qram-01-2015-0008

Ittner, C.D., Larcker, D.F., \& Randall, T. (2003). Performance implications of strategic performance measurement in financial services firms. Accounting, Organizations \& Society, 28(7/8), 715-741. https://doi.org/10.1016/s0361-3682(03)00033-3

Jones, P., Comfort, D., \& Hillier, D. (2006). Corporate social responsibility and the UK construction industry. Journal of Corporate Real Estate, 8(3), 134-150. https:// doi.org/10.1108/14630010610711757

Kaplan, R.S., \& Norton, D.P. (1996). The Balanced Scorecard: Translating strategy into action. Harvard Business School Press. 
Kaplan, R.S., \& Norton, D.P. (2001). Transforming the Balanced Scorecard from performance measurement to strategic management: Part I. American Accounting Association, 15(1), 87-104. https://doi.org/10.2308/acch.2001.15.1.87

Kaplan, R.S., \& Norton, D.P. (2004). Measuring the strategic readiness of intangible assets. Harvard Business Review, 82(2), 52-63.

Knutson, B.J. (1988). Frequent travelers: Making them happy and bringing them back. Cornell Hotel and Restaurant Administration Quarterly, 29(1), 83-87. https:// doi.org/10.1177/001088048802900121

Laitinen, E.K. (2002). A dynamic performance measurement system: Evidence from small Finnish technology companies. Scandinavian Journal of Management, 18, 65-99. https://doi.org/10.1016/s0956-5221(00)00021-x

Langfield-Smith, K. (1997). Management control systems and strategy: A critical review. Accounting, Organizations and Society, 22(2), 207-232. https://doi.org/10.1016/ s0361-3682(95)00040-2

Lu, C., Berchoux, C., Marek, M.W., \& Chen, B. (2015). Service quality and customer satisfaction: Qualitative research implications for luxury hotels. International Journal of Culture, Tourism and Hospitality Research, 9(2), 168-182. https:// doi.org/10.1108/ijcthr-10-2014-0087

Marr, B., \& Schiuma, G. (2003). Business performance measurement-past, present and future. Management Decision, 41(8), 680-687. https://doi. org/10.1108/00251740310496198

Meyer, M.W. (2002). Rethinking performance measurement: Beyond the Balanced Scorecard. Cambridge University Press.

Ministry of Tourism and Sport. (2015). Tourism economic review no. 2 (OctoberDecember). http://www.mots.go.th/ewt_dl_link.php?nid=7534.

Mohsin, A., \& Lockyer, T. (2010). Customer perceptions of service quality in luxury hotels in New Delhi, India: An exploratory study. International Journal of Contemporary Hospitality Management, 22(2), 160-173. https://doi. org/10.1108/09596111011018160

Neely, A. (2005). The evolution of performance measurement research: Developments in the last decade and a research agenda for the next. International Journal of Operations \& Production Management, 25(12), 1264-1277. https://doi. org/10.1108/01443570510633648

Neely, A., Adams, C., \& Crowe, P. (2001). The performance prism in practice. Measuring Business Excellence, 5(2), 6-12.

Neely, A., Adams, C., \& Kennerley, M. (2002). The performance prism: The scorecard for measuring and managing business success. Prentice Hall Financial Times.

Neely, A., Gregory, M., \& Platts, K. (1995). Performance measurement system design: A literature review and research agenda. International Journal of Operations \& Production Management, 15(4), 80-116. https://doi. org/10.1108/01443579510083622

Neely, A., Gregory, M., \& Platts, K. (2005). Performance measurement system design: A literature review and research agenda. International Journal of Operations \& Production Management, 25(12), 1228-1263. https://doi. org/10.1108/01443579510083622 
Nudurupati, S.S., Bititci, U.S., Kumar, V., \& Chan, F.T.S. (2011). State of the art literature review on performance measurement. Computers \& Industrial Engineering, 60(2), 279-290. https://doi.org/10.1016/j.cie.2010.11.010

Pazir, D., \& Amin, I. (2015). A study of customer satisfaction towards hotel industry in Kashmir Valley. International Journal of Management Research \& Review, 5(12), 1117-1123.

Plessis, A.J.D, Douangphichit, N., \& Dodd, P. (2016). HRM in relation to employee motivation and job performance in the hospitality industry. Journal of International Business Research and Marketing, 1(4), 12-21. https://doi.org/10.18775/ jibrm.1849-8558.2015.14.3002

Porter, M.E., \& Kramer, M.R. (2006). Strategy and society: The link between competitive advantage and corporate social responsibility. Harvard Business Review, 84(12), 78-92.

Porter, M.E. (1992). Capital disadvantage: America's failing capital investment system. Harvard Business Review, 70(5), 65-82.

Purnomo, D.S., Sucherly, Suryana, Y.S., \& Sari, D. (2018). The effect of business partnership and innovation management to business performance of business units of multiplay provider in Indonesia. Academy of Strategic Management Journal, 17(2), 1-12.

Rajnoha, R., Lesníková, P., \& Korauš, A. (2016). From financial measures to strategic performance measurement system and corporate sustainability: Empirical evidence from Slovakia. Economics and Sociology, 9(4), 134-152. https://doi. org/10.14254/2071-789x.2016/9-4/8

Rasid, A.S.Z., Golshan, N., Mokhber, M., Tan, G.G., \& Mohd-Zamil, N. (2017). Enterprise risk management, performance measurement systems and organizational performance in Malaysian public listed firms. International Journal of Business and Society, 18(2), 311-328. https://doi.org/10.33736/ijbs.543.2017

Roshan, D., \& Jenson, J.E. (2014). Study on performance measurement systems: Measures and metrics. International Journal of Scientific and Research Publications, 4(9), $1-9$.

Salvato, C., \& Moores, K. (2010). Research on accounting in family firms: Past accomplishments and future challenges. Family Business Review, 23(3), 193215. https://doi.org/10.1177/0894486510375069

Schneier, C.E. (1991). Performance measurement and management: A tool for strategy execution. Human Resource Management, 30(3), 279-301. https://doi. org/10.1002/hrm.3930300302

Simons, R. (2000). Performance measurement and control systems for implementing strategy: Texts and cases. Prentice-Hall.

Srimai, S., Radford, J., \& Wright, C. (2011). Evolutionary paths of performance measurement: An overview of its recent development. International Journal of Productivity and Performance Management, 60(7), 662-687. https://doi. org/10.1108/17410401111167771

Tapera, J. (2014). The importance of strategic management to business organizations. Research Journal of Social Science \& Management, 3(11), 122-131. 
Thompson, A.A, Peteraf, M.A., Gambel, J.E., \& Stricklland III, A.J. (2016). Crafting and executing strategy: The quest for competitive advantage, concepts and readings (20nd ed.). McGrew-Hill Education.

United Nations World Tourism Organization (UNWTO). (2017). UNWTO tourism highlight: 2017 edition. https://www.e-nwto.org/doi/book/10.18111/97892844 19029. https://doi.org/10.18111/9789284419029

Wuest, B.S. (2001). Service quality concepts and dimensions pertinent to tourism, hospitality, and leisure services. In J. Kandampully, C. Mok, and B. Sparks (Eds.). Service quality management in hospitality, tourism, and leisure (pp. 5166). Haworth Press. https://doi.org/10.4324/9780203047965 